\title{
Phase Composition of Mechanically Alloyed Titanium and Iron Aluminides
}

Adriana Bernatiková, Filip Průša, Pavel Novák

University of Chemistry and Technology Prague, Department of Metals and Corrosion Engineering, Technická 5, 16628 Prague 6, Czech Republic, E-mail: bernatia@vscht.cz

\begin{abstract}
Aluminides belong in these days group of materials, which can be used as a good replacement of stainless steels, for whom they owe attractive mechanical properties, or nickel superalloys, which are too heavy. These materials are used in aerospace industry as well as in automotive industry. Good corrosion and oxidation resistance and high specific strenght even up to high temperatures predict them to be also used for high temperature applications. In this paper, mechanical alloying was used. During mechanical alloying differences between TiAl and FeAl systems were seen. Iron aluminide formed single phased structure, whereas titanium aluminide formed preferentially two-phase structure.
\end{abstract}

Keywords: mechanical alloying, titanium aluminides, iron aluminides, phase composition

\section{Acknowledgements}

This research was financially supported by Czech Science Foundation, project No. 17-07559S and by specific university research (MSMT No 20-SVV/2017).

\section{References}

[1] ZHANG, Z., LI, X., DONG, H. (2015). Extremely-low-cycle fatigue behaviors of Cu and Cu-Al alloys: Damage mechanisms and life prediction. In: Acta Materialia, Vol. 83, No. 15, pp. 341-35. Elsevier, UK

[2] KOTHARI, K., RADHAKRISHNAN, R., WERELEY, N. M. (2012). Advances in gamma titanium aluminides and their manufacturing techniques. In: Progress in Aerospace Sciences, Vol. 55, pp. 1-16. Elsevier, USA

[3] NESPER, R. (1996). Intermetallics. In: Angewandte chemie, Vol. 108, No. 6, pp. 726-727. WILEY-VCH, Germany

[4] ABDALLAH, Z., DING, R., MARTIN, N., DIXON, M., BACHE, M. (2016). Creep deformation mechanisms in a $\gamma$ titanium aluminide. In: Materials Science \& Engineering A, Vol. 673, No. 15, pp. 616-623. Elsevier, UK

[5] ŁYSZKOWSI, R., BYSTRZYCKI, J. (2014). Hot deformation and processing maps of a Fe-Al intermetallic alloy. In: Materials Characterization, Vol. 96, pp. 196-205. Elsevier, Poland

[6] NEGACHE, M., TAIBI, K., SOUAMI, N., BOUCHEMEL, H., BELKADA, R. (2013). Effect of Cr, Nb and Zr additions on the aqueous corrosion behavior of iron-aluminide. In: Intermetallics, Vol. 36, pp. 73-80. Elsevier, Algeria

[7] PRŮŠA, F., VOJTĚCH, D., BERNATIKOVÁ, A., DVORSKÝ, D. (2015). Mechanical alloying: A way how to improve properties of aluminium alloys. In: Manufacturing Technology, Vol. 15, No. 6, pp. 1036-1043, Czech Republic.

[8] NOVÁK, P., SALVETR, P., PECENOVÁ, Z. (2015). Intermetallics - Synthesis, production, properties, In: Manufacturing Technology, Vol. 1ř, No. 6, pp. 1024-1028, Czech Republic

[9] SURYANARAYANA, C., CHEN, G.-H., FREFER, A., FROES, F. H. (1992). Structural evolution of mechanically alloyed TiAl alloys. In: Materials Science and Engineering, Vol. 158, No. 1, pp. 93-101, University of Idaho, USA

[10] BEKE, D. L., BAKKER, H., LOEFF, P. I. (1991). On the elastic mismatch in the order-disorder transformation and solid state amorphization of intermetallic compounds-II. Criteria for the solid-amorphous transformation in intermetallic compounds. In: Acta Metallurgica, Vol. 39, pp. 1267-1273, Great Britain

[11] BASU, S., SHANKAR, M. R. (2014). Microstructure and deformation during serve shear deformation at small length-scales. In: Scripta Materialia, Vol. 72-73, pp. 51-54, Elsevier, USA 